\title{
The Utilization of GSO by Indonesia as a Subjacent State Based on Space Treaty 1967
}

\author{
Richo Wembi Rajanun Nafis ${ }^{1 *}$, M. Kabul Supriyadhie ${ }^{2}$, Adya Paramita P. ${ }^{3}$ \\ \{richonafis@gmail.com ${ }^{* 1}$, kabul.supriyadhie@live.undip.ac.id. ${ }^{2}$, adyapprabandari@ gmail.com ${ }^{3}$ \}
}

Fakultas Hukum, Universitas Diponegoro, Jl. Prof. H. Soedarto, S.H., Semarang, Indonesia $50275^{1}$

\begin{abstract}
GSO is a ring-shaped orbit located at six earth radians above the equator, and is the most strategic place to place satellites because they are in a fixed position in space against the earth. The existence of the principle of first come, first served makes injustice in the use of GSO. This makes the countries where positions are under the GSO region or under the state demand for justice for the use of GSO which must be in fair, equitable and rational for the common good. Issues that will be discussed in the writing of this law are: (1) Indonesia's position as a nation under the International Law, (2) the use of GSO by Indonesia as a country under the 1967 Space Treaty. The research uses a normative juridical approach with descriptive analytical research specifications. The source of the data is secondary data collecting from literature study. The method of data analysis is qualitative analysis. The results of research is that Indonesian territory may be affected by celestial bodies that can threaten the safety of Indonesian citizens. By ratifying the 1972 Liability Convention, Indonesia as an underdeveloped country has the right to claim damages to the launching country when their satellite or space object falls onto Indonesian territory, and incur losses.
\end{abstract}

Keywords: GSO; Indonesia; 1967 Space Treaty.

\section{Introduction}

The development of technology at this time is something that must be taken into account for any country. Each country is trying to launch satellites into space to meet the interests of their country. The launch of the Sputnik I satellite by the Soviet Union in 1957 and followed by the United States had triggered other countries to carry out activities in space.

With the development of activities in space, the principle that the sovereign state of the airspace above it to an unlimited height becomes invalid. Space requires its own arrangements that are different from the airspace settings of a country. Then, on January 27, 1967, a treaty governing space was signed namely the Treaty on Principles of Governing the Activities of States in the Exploration and Use of Outer Space, Including the Moon and Other Celestial Bodies (Space Treaty 1967). In Articles I and II of the Space Treaty 1967 states that space is the property of all people. Therefore, it cannot be made an object of ownership or sovereignty by a country and used freely for the common their own interests.[1]

One of the activities in space is the use of Geostationary Orbit (GSO) which has a strategic position for satellite placement. Indonesia, as a country under the certainty of the existence of the GSO has very important roles. Conducting GSO utilization activities must be in accordance with applicable regulations, in 2002 Indonesia ratified the 1967 Space Treaty as stipulated in Law No. 16 of 2002 concerning the ratification of the Space Treaty1967. Thus in 
carrying out activities of utilizing the GSO Indonesia, it must comply with the applicable rules.

In writing the paper,, the formulation of the problem to be discussed is as follows:

1. What is the position of Indonesia as a niche in International Law?

2. How is the use of GSO by Indonesia as a country under the 1967 Space Treaty?

\section{Method}

The method of approach used in this study is normative juridical research. It is legal research conducted by examining literature or secondary data as a basic material to be investigated by searching for regulations and literature relating to the problem under study.[2]

The research specifications used in this study are analytical descriptive. Data analysis used in this study is a qualitative analysis in which the results of the study will be described in the form of sentences which are arranged systematically.

\section{Results and Discussion}

\subsection{The Position of Indonesia as a Colle State in International Law}

\subsubsection{Space Delimitation}

The development of human activities in air space and space raises legal controversy. So the need for a dividing line between air space and space.[3] However, several theories emerge that can be used to determine the limits of air space and space as follows:[3]

\section{a. The boundary line theory is based on the conception of the atmosphere}

According to this theory, air space and space are limited by the height of the atmosphere. The higher the atmosphere, the greater the pressure., As a result, the piston / jet powered aircraft will not be able to fly at a certain height, and only planes that are powered by rockets can fly to that height.

\section{b. The theory of atmospheric division}

According to this theory, the limits of air space and space are based on the maximum height an airplane can fly, precisely in the stratosphere region only. The rest is the area of space.

\section{c. Von karman theory}

According to the theory, the limits of air space and space based on an elevation the aerodynamic lift can work on an aircraft that is at an altitude of 90-100 km above sea level.

\section{d. Perigee theory / lowest point of a satellite}

According to this theory, air space and space are limited to the lowest point of a satellite orbiting the earth, which is approximately $160 \mathrm{~km}$ above sea level.

e. Line theory is based on the point where there is no attraction to the earth 
According to this theory, it is believed that the boundary of the air-space space ends at the point where the attraction of the earth is gone or rather the attraction of the earth is getting smaller.

\section{f. Strength theory}

According to this theory, the limits of air space and space are based on the technical ability of a country in carrying out a real supervision that can be done with the ability to technically reach the air space / space of a country.

\section{g. Zone theory}

According to this theory, the airspace is divided into airspace which is subject to sovereignty and a crossing area which is $150-240 \mathrm{~km}$ above sea level. And above these two zones is free space.

From 7 (seven) theories mentioned above, it shows that the division of boundaries between air space and space is a vital thing. It relates to the legal implications about the rights and responsibilities of space activities that are different from flight activities using airplanes. Of the various proposals submitted, but until now there has been no international agreement regarding the determination of the boundaries of air space and space. This is because there are different points of view and different interests in the use of space.[3]

On the one hand, there is a group that holds that space delimitation is needed, and on the other hand, there are other groups who view such delimitation as unnecessary. The reasons for those who consider the need for this delimitation are: to guarantee legal certainty; the fact that airplanes can only fly in airspace and cannot fly in vacuum, otherwise the requirements are not absolutely treated for spacecraft; formulate legal provisions to prevent military activities in space.

The reasons of those who deem unnecessary delimitation are: the existence of delimitation will expand the demands on the country's sovereign territory; will cause problems with crossing rights and status of the spacecraft; in fact the physical boundary between air space and space is very thin and very difficult to determine with certainty.

Based on the above conditions, it can be seen that the discussion of space delimitation issues tends to the problem of establishing a special legal regime, whether the special legal regime is called aerospace object, sub-orbital flight and space traffic management.[4]

The aerospace object regime, where the definition of an aerospace object is, "an object which is capable of both of traveling through outer space and using its aerodynamic properties to remain in airspace for a certain period of time."[5] Determination of this regime can be said as a functional approach. If this is applied, the determination of air and space boundaries is not necessary. The purpose of this legal regime is based on where the aerospace object is, whether in air space or in space which will produce practical problems related to the application of law.

Whereas the sub-orbital flight regime with the definition of sub-orbital flight is a flight with altitude above the civil flight. The establishment of this regime indicates a new zone outside air and space that regulates human activities in using technology in the zone. This arrangement makes the activities in it special. So, if there are conflicts with the air and space, the regime will harmonize it.[4]

In the space traffic management (STM) regime, where the STM is defined, "Space Traffic Management means the set of technical and regulatory provisions for promoting safe access into outer space, operation in outer space and return from outer space to earth free from physical or radio frequency interference ". This regime indicates the management of space 
traffic which leads to special provisions for the purpose of space traffic safety. The enactment of this regime means the formulation of regulations that are more technical in nature and are only for safety purposes. Therefore, the establishment of this regime must respect existing air and space laws in conducting space traffic. [4]

From the description above, it can be concluded that the three regimes above can be used as problem solvers regarding space delimitation by using a functional approach to aerospace objects that are based on the function or mission of the object and not using a spatial or regional approach, zoning system for sub-orbital flight which creates its own zone, and a system that regulates space traffic safety for space traffic management.

Regarding the above problems, Indonesia has its own views. At the UNCOPUOS session in 1998, Indonesia in essence conveyed its views regarding aerospace objects which explicitly stated that in formulating space delimitation, it should use an approach that considers the special needs of developing countries. At the 2003 National Aerospace Congress, Indonesia adopted a spatial approach in determining space delimitation. Then, in Act Number 21 of 2013 concerning Space, it does not explicitly mention space delimitation. But Article 1 Number 1 contains the definition of space, namely "Space is the space and its contents which are located outside the air space which surrounds and surrounds the air space". Article 1 Number 2 contains the definition of Space which is "Space is everything about Space and relating to the exploration and utilization of space".

From this understanding, it is reflected that space activities include not only space in the sense of territory but also all activities carried out in the context of exploration and use. From the contents of these two Articles, it can be seen that Indonesia is aiming at a functional approach in the case of space delimitation. However, in a general explanation, it is stated "Space is a space and its contents that are outside the air space, as well as those that surround and enclose the air space. Naturally Space is located about $100-110 \mathrm{~km}$ above the air space or Earth's atmosphere.[4]

From the description above Indonesia's attitude reflected changing indications. However, in essence, if in 2003, Indonesia was positioned as a spatial state based on the results of the 2003 congress, then in Law Number 21 Year 2013 on Space would indicate a functional approach. Whereas in the general explanation it indicates a spatial approach.

\subsubsection{Indonesia's Position as a Colong Country}

Indonesia as a country whose territory is under the longest GSO lane can make it possible for Indonesia to be hit by satellites or other countries' spacecraft. This is supported by the increase in the number of man-made celestial launches into space. the possibility of malfunction can not be avoided, and also satellites whose lifetime has been depleted will cause more space objects that can fall to earth.

Judging from the consequences, as is known that there are man-made celestial bodies launched into space using nuclear power. So if the object falls in the territory of the country below it can cause disruption to the health / safety of humanity and other creatures.

The effects that can be caused by the fall of celestial bodies that still contain radioactive material that falls on the surface of the earth can be stated as follows:[6]

a. Short-term effects, divided into two types, namely mild and severe types. Symptoms that appear in the mild type are: sore throat, fever, malaise, fatigue, and hemoglobin and leukocytes will decrease dramatically. Severe types are characterized by symptoms such as: the onset of certain diseases (skin, lung, bone, etc.). 
b. Long-term effects, damaging to genetic material that can cause abnormalities in the genesis of offspring., Humans affected by this long-term effect will result in offspring born in a state of disability.

c. The slow effect, which is radiation that hits the body that will damage the organs of the body slowly and only cause fatal danger after years.

Contamination of other objects around the location of the fall of the celestial body, among others, in the air, drinking water, food, grass where at a certain time will also cause harm to humans who come in contact with these objects.

During the fall of the Soviet Union Cosmos 954 Satellite carrying nuclear power sources in the form of uranium with isotope 235, on January 24, 1978 at 11.53 GMT it had entered the Earth's atmosphere and crashed north of the Queen Charlotte islands off the coast of Canada. From the results of operations that have been carried out in two stages has produced a conclusion that the fall of the satellite has caused nuclear radiation.

As one of the countries under the earth, the possibility of being hit by space objects both in the form of satellites and other forms can occur in areas of Indonesia whose population is also quite large. Then, it needs a special international law to protect the affected countries in order to obtain compensation. There are two international treaties that contain basic provisions regarding responsibilities in space law, namely, the 1967 Space Treaty and the 1972 Liabillity Convention. Then the provisions are detailed again in the 1972 Space Liability Convention. [7]

Under the convention, the launching country is responsible for compensating the countries affected by the launching state's celestial bodies. This obligation is stated in Article II of Space Liability 1972, "A launching state shall be absolutely liable to pay compensation for damage caused by its object space on the surface of the earth or to aircraft in flight". Whereas what is meant by launching state in Article I letter c, is, "1) A state launches or procures the launching of space object; 2) A state frome whose territory or facility a space object is launched."

So, based on the above article, launching countries are not only countries that launch celestial objects, but also countries that have the opportunity to participate in launching celestial objects, and countries whose territories or facilities provide a space object launch. In this case, these countries are partially responsible for the losses caused by the launch.

There are two principles of liability in the 1972 Liability Convention. The first principle is absolute liability. This principle can be used when losses occur on the surface of the earth, such as being hit by a building by a piece of celestial body, damaging to nature due to nuclear contamination on the surface of the earth, and causing casualties because of the celestial body. The second principle is liability based on fault (liability based on fault). This principle is used when losses occur not on the surface of the earth and in the air. However, losses occur in spaceships, for example in the case of celestial bodies which cause damage due to crashing into other celestial bodies belonging to other launching states that have been placed in their orbits.

When viewed from the perspective of the country underneath (the country that was struck) then this is very beneficial. Indonesia itself has ratified the 1972 Liability Convention set forth in KEPPRES No.20 of 1996 concerning the ratification of the Convention on International Liability for Damage Caused by Space Objects, 1972 (Convention on International Responsibility for Losses caused by Space Objects, 1972). So if there are satellites or other celestial objects that fall in the territory of Indonesia and cause losses, then the responsibility can be asked to the launching country that launched the satellite or celestial body. 
From the description above, it can be seen that with the ratification of the 1972 Liability Convention, Indonesia as an underdeveloped country has the right to claim damages to launching countries if their satellites or space objects fall into Indonesian territory and cause losses.

\subsection{Utilization of GSO by Indonesia as a Blank Country Based on the 1967 Space Treaty}

\subsubsection{Legal Regulations on the Use of GSO}

Geostationary Orbit is an orbital path above the equator at an altitude distance of approximately $35,871 \mathrm{~km}$ from the earth's surface. An object (such as a satellite) placed in the orbit has the same rotation time as the Earth's rotation time.[8] So, objects placed in GSO's orbit appear to be stationary on that orbit.

In the case of GSO utilization, there are legal provisions specifically regulating the use of the GSO. In the 1967 Space Treaty Article I, II, and IV which essentially states that in the use of space which includes GSO, the moon and other celestial bodies must be fair and without discrimination, it should not be used as an object of ownership of a country in any way , as well as in its use must be done for peaceful purposes. The article is the basis for countries in the use of GSO.

In the 1973 ITU Convention said that, GSO is a limited natural resources (limited natural resources), and each country gets a fair share and can use it fairly (equitable access). This is stated in the amendment to the formulation of Article 33 paragraph 2 of the ITU Convention, namely, "all countries have equal access for space radio communication services and positions in the GSO".[9] From the amendment to the formulation, it can be seen that all countries have an opportunity of fair access to use GSO.

\subsubsection{Utilization of GSO by Indonesia}

Utilization of Geostationary Orbit (GSO) which previously could only be used by developed countries, especially the United States and the Soviet Union when they were in the Cold War atmosphere. Today, many developing countries including Indonesia have also been able to utilize the GSO slot. Previously through international forums countries that felt disadvantaged (developing countries) because they could not utilize the GSO struggled to assert their right to be able to take advantage of the GSO. Because at that time it was undeniable that there was an injustice in the use of GSO, where only developed countries could enjoy the orbit because it had adequate technological and economic capabilities. Whereas developing countries cannot utilize these orbits.

GSO has a unique orbital nature, where celestial bodies placed in these orbits will seem to be stationary. Because of its unique nature, many countries want to place their satellites on the GSO. However, given that GSO is a limited natural resource, it must be maintained so that there is no saturation in its utilization by calculating the capacity of the GSO path.[10] The following are some of the activities that utilize the GSO path as follows:

\section{a. Remote sensing (remote sensing)}

Remote sensing is a method of identifying systems of nature and / or determining the condition of objects on the surface of the earth and goods below or above them by means of observation from the air and space platforms. Remote sensing has a positive impact on human life, for example for the management of natural resources, environmental development, increase food production, weather forecasts, natural disaster management, settlement planning 
and land use, mapping, and others. But remote sensing also has a negative impact on countries today. With remote sensing, a country can spy on other countries. Therefore the country conducting remote sensing must obtain permission from the country that was targeted for sensing. Then the results of the sensing must be notified to the country which is the object of sensing so that there is no misuse of the results or data from the sensing. [3]

In 1975, the UNCOPUOS legal subcommittee reached agreement on several important elements in remote sensing, namely:[8]

1) That remote sensing activities using space technology should be done for the benefit and benefit of all humanity.

2) The activity must be carried out in accordance with the provisions of international law and the UN Charter and in accordance with the 1967 Space Treaty.

3) Countries that implement remote sensing programs through space technology should invite the participation of other international communities.

4) These activities actions need to be taken to protect the earth's environment.

\section{b. Telecommunications and Information}

This telecommunications and information activity initially focused on the importance of service and search rescue. However, in its development, it then expanded its services to become a global communication network for mobile communication services, for example those engaged in publishing, management, data, law, bookkeeping, advertising, and a sharp increase in the types of communication space from just voice becomes other services such as navigation, direct broadcasting, messages, digital radio, multimedia. Then also the expansion of the use of the earth's orbit and the development of global information infrastructure network services.[11]

For Indonesia, the use of GSO is very important for the welfare of the Indonesian people. Indonesia's interests in the use of GSO are actually stated in the Preamble to the 1945 Constitution of the Republic of Indonesia through the placement of communication satellites for the benefit of Indonesia. The basic interest of every nation and state is its survival which must be filled with a struggle to achieve its national goals and objectives. In this case the basic national interests that need to be defended and fought for by the Indonesian people are:[9]

1) The protection of the Indonesian nation and the integrity of the national territory of the Republic of Indonesia from any challenges, threats, obstacles, and disturbances that come from outside or inside.

2) The creation and maintenance of national stability, and the occurrence of regional and international stability for the success of Indonesia's subsequent national development.

3) Maintaining world order based on freedom, lasting peace and social justice.

The above interests of Indonesia can be realized through the use of GSO, namely by utilizing the results of scientific and technological advances and GSO potential as much as possible to support national development, in order to realize national goals and objectives as contained in the Preamble to the 1945 NRI Constitution.

Indonesia's decision to have its own communication satellite is a strategic decision, because its benefits can unite the nation and spur the development of communication technology and Indonesian space technology. In addition to the use of GSO through the use of satellites that are owned and operated by themselves, Indonesia also utilizes satellites from other countries or international organizations stationed at GSO for weather monitoring, environmental monitoring and navigation of air and sea traffic. Realizing that the GSO has the potential to be used for other purposes, it is possible that in the future Indonesia will also take 
advantage of the GSO for the purposes in the fields of application above. With the condition and status of the use of GSO has become a vital area of interest in Indonesia.

The above interests of Indonesia can be realized through the use of GSO, namely by utilizing the results of scientific and technological advancements and GSO potential as much as possible to support national development, in order to realize national goals and objectives as contained in the Preamble to the 1945 NRI Constitution.

Based on the above facts, Indonesia's interests in GSO both now and in the future are:[9]

1) Guaranteeing the continuity of the use of GSO by Indonesia for the purposes of telecommunications, broadcasting, and meteorology as well as the possibility of developing other fields.

2) Guaranteeing Indonesian satellites from all threats and interference from other parties that can harm Indonesia.

3) Guaranteeing GSO from its use. It may have a negative impact both on the environment of the GSO itself and the earth, especially on the territory of Indonesia.

4) an opportunity for Indonesia to use the orbit slot and frequency spectrum at any time in the GSO at any time if needed at the national interest.

5) Condemning the use of GSO from all forms of activities that are not for peaceful and humanitarian purposes.

With the existence of international rules governing the GSO, in accordance with the principles of justice and non-discrimination in the use of space listed in Article I Space Treaty 1967 and Article 33 paragraph 2 ITU Convention 1973 makes developing countries able to utilize the GSO for the benefit of their countries . Indonesia currently has satellites operating on the GSO and non-GSO lines. The most important thing is that the use of GSO channels through local satellites and satellites from other countries is used to improve the welfare and security of Indonesian citizens' lives.

\section{Conclusion}

1) In the case of determining the delimitation of space up, there is no international agreement on this matter, and instead, it tends to use a functional approach. Meanwhile, Indonesia is more inclined to a spatial approach. Then, with the enactment of Presidential Decree No. 20 of 1996, Indonesia has the right to claim compensation from launching countries if their satellites or space objects fall into Indonesian territory.

2) The use of GSO must be done fairly, and is without discrimination. Its use must be carried out for peaceful purposes. For Indonesia, the use of GSO can be done through the placement of communication satellites, weather through observations, navigation, and others whose purpose meets the interests of the Indonesian state, in particular, improving the welfare of its citizens without violating applicable regulations. 


\section{References}

[1] A. Pramono, Hukum Keruangangkasaan Perspektif Internasional dan Nasional. Semarang: Pustaka Rizki Putra, 2016.

[2] S. Soekanto and S. Mamudji, Penelitian Hukum Normatif. Jakarta: Raja Grafindo Persada, 1985.

[3] A. Pramono, Dasar-Dasar Hukum Udara dan Ruang Angkasa. Jakarta: Ghalia Indonesia, 2011.

[4] Mardianis, "Masalah Definisi dan Delimitasi Antariksa: Analisis Kecenderungan Pengaturan dan Posisi Indonesia," Pus. Kaji. Kebijak. Penerbangan dan Antariksa LAPAN, pp. 65-86, 2016.

[5] S. Gorove, "Aerospace object-legal and policy issues for air and space law," J. Sp. L., vol. 52, no. 2, p. 101, 1997.

[6] J. Sumardi, Hukum Ruang Angkasa (Suatu Pengantar). Jakarta: Pradnya Paramita, 1996.

[7] D. Verschoor, Persamaan dan Perbedaan Antara Hukum Udara dan Hukum Ruang Angkasa. Jakarta: Sinar Grafika, 1991.

[8] P. Abdurrasyid, Hukum Antariksa Nasional (Penempatan Urgensinya). Jakarta: Rajawali Pers, 1989.

[9] A. Pramono, "Orbit Geostasioner (GSO) dalam Hukum Internasional dan Kepentingan Nasional Indonesia," Pandecta, vol. 6, no. 2, pp. 128-138, 2011.

[10] E. S. Wiradipradja, M. K. Kantaatmadja, and T. Saefullah, Hukum angkasa dan perkembangannya. Bandung: Remadja Karya, 1988.

[11] I. B. R. Supancana, Peranan Hukum Dalam Pembangunan Kedirgantaraan (Kumpulan Makalah dan Paparan Ilmiah). Jakarta: Mitra Karya, 2003. 